\author{
Monika Borowiec \\ Sławomir Dorocki \\ Uniwersytet Pedagogiczny \\ im. Komisji Edukacji Narodowej \\ w Krakowie
}

\title{
Rozwój Krynicy-Zdroju jako wynik przedsiębiorczych działań władz samorządowych
}

\author{
Development of Krynica-Zdroj as the result of entrepreneurial activities of local \\ authorities
}

\begin{abstract}
Streszczenie
Wzrost zamożności i mobilności mieszkańców Polski, wraz z globalnymi zmianami trendów w sposobie spędzania wolnego czasu, wpływają na przemiany dotyczące funkcjonowania polskich miejscowości uzdrowiskowych i zwiększające się znaczenie nowoczesnych form turystyki zdrowotnej w rozwoju gospodarczym kurortów. W niniejszym artykule podjęto problematykę zmian funkcjonowania i zagospodarowania przestrzennego jednego z najważniejszych polskich uzdrowisk - Krynicy-Zdroju - na podstawie wyników prowadzonych badań ankietowych. Zmierzano do odpowiedzi na pytanie, czy podejmowane przez władze samorządowe kierunki przekształceń pobudzają rozwój gospodarczy i w jaki sposób działania te wpływają na postrzeganie uzdrowiska, zarówno przez turystów, jak i mieszkańców miasta.
\end{abstract}

\begin{abstract}
The increasing prosperity and mobility of Polish citizens along with global changes in the way people spend their leisure time affect the operation of Polish spa resorts and towns, and increase the importance of developing modern forms of health tourism for the economies of spa resorts. The article discusses the problem of changes in the operation and spatial development of one of the most important Polish spa town Krynica-Zdroj based on the survey results. It seeks to answer the question whether the directions of transformation undertaken by the local authorities stimulate economic development and how they influence the perception of Krynica-Zdroj by both the tourists and town's residents.
\end{abstract}

Słowa kluczowe: Krynica-Zdrój; przedsiębiorczość; samorząd; strategia rozwoju; uzdrowisko Key words: entrepreneurship; local government; Krynica-Zdroj; strategy of development; spa

\section{Wprowadzenie}

Współcześnie nasilające się procesy przemian społeczno-ekonomicznych wpływają na zmiany funkcjonowania polskich miejscowości uzdrowiskowych i zwiększanie znaczenia turystyki uzdrowiskowej w rozwoju gospodarczym układów przestrzennych. W Marketingowej strategii Polski w sektorze turystyki na lata $2008-2015^{1}$ przyjęto, że trzeba nie tylko zintensyfikować

\footnotetext{
${ }^{1}$ www.pot.gov.pl/plany-i-sprawozdania-pot/marketingowa-strategia-polski-w-sektorze-turystyki-nalata-2008-2015.
} 
działania promocyjne na rzecz kształtowania pozytywnego wizerunku uzdrowisk polskich, lecz także, w związku z rosnącymi wyzwaniami, położyć większy nacisk na tworzenie innowacyjnego produktu uzdrowiskowego. Procesy te wyraźnie zaznaczają się na obszarze kurortów w województwie małopolskim. Ważnym wyzwaniem, przed którym stoją uzdrowiska, jest zmiana zakresu świadczonych usług, poprzez wykraczanie poza działania związane tylko z lecznictwem uzdrowiskowym. W wyniku konsekwentnie realizowanej dywersyfikacji usług będą one mogły skuteczniej konkurować z placówkami europejskimi. Problematyka ta była podejmowana w licznych pracach (m.in.: Golba, 2002; Kaczmarska, 2002; Lewandowska, 2005; Krupa, Wołowiec, 2010; Lasak, 2010; Kłos, 2011; Wołowiec, Reśko, 2012; Zaręba, 2012; Dorocki, Brzegowy, 2013).

Jednym z najważniejszych i najbardziej znanych uzdrowisk w Polsce jest Krynica-Zdrój, określana jako perła polskich uzdrowisk. Jest to stolica pieśni operowych i operetkowych, ojczyzna słynnego malarza prymitywisty Nikifora Krynickiego oraz centrum sportów zimowych. Miasto położone jest w Beskidzie Sądeckim, w dolinach Kryniczanki i jej dopływów: Palenicy, Słotwinki i Czarnego Potoku, na obszarze Popradzkiego Parku Krajobrazowego utworzonego w 1987 r. Krynica-Zdrój znajduje się również na Szlaku Architektury Drewnianej oraz Trakcie Cerkwi Łemkowskich. Podstawą rozwoju funkcji uzdrowiskowych w Krynicy-Zdroju są przede wszystkim wody mineralne. Obecnie czerpie się je z 23 ujęć, w tym 5 źródeł naturalnych i 18 odwiertów. Ponadto surowcem leczniczym wykorzystywanym w kurorcie jest borowina pozyskiwana ze złoża torfowego w Mochnaczce Niżnej. Krynica-Zdrój, jako jedyne uzdrowisko w kraju, oferuje także tzw. suche kąpiele gazowe, stosując w tym zabiegu naturalny bezwodnik kwasu węglowego, pochodzący ze źródła Zuber. Jakkolwiek Krynica-Zdrój znana jest przede wszystkim jako uzdrowisko, to jest ona także intensywnie rozwijającym się ośrodkiem sportowym, turystycznym, rekreacyjnym, kulturalnym i kongresowym, na co wskazuje wiele cyklicznych imprez krajowych i międzynarodowych, plenerów, spotkań kulturalnych oraz konferencji politycznych i naukowych, które są tam organizowane. Miasto to jeden z największych i najstarszych polskich ośrodków sportów zimowych oraz kolebka polskiego saneczkarstwa. Ważnym czynnikiem jego rozwoju jest organizowane już od 20 lat Forum Ekonomiczne, które gromadzi systematycznie zwiększające się, międzynarodowe grono ekspertów i liderów życia politycznego, społecznego, gospodarczego oraz kulturalnego. Towarzyszy temu rozwój turystyki, m.in. tzw. turystyki konferencyjnej, stającej się coraz ważniejszym motorem zmian w zagospodarowaniu przestrzennym i planach inwestycyjnych miasta ${ }^{2}$.

Wyrazem dostrzeżenia zwiększającego się znaczenia turystyki uzdrowiskowej w rozwoju gospodarczym układów przestrzennych oraz konieczności intensyfikowania współpracy i przekształceń gmin uzdrowiskowych jest m.in. realizacja przez Instytut Turystyki w Krakowie Sp. z o.o. projektu Partnerstwo na rzecz adaptacyjności i modernizacji uzdrowisk województwa małopolskiego, współfinansowanego ze środków Europejskiego Funduszu Społecznego. Cele projektu obejmują określenie stymulatorów i barier rozwoju uzdrowisk w województwie małopolskim, stworzenie platformy wymiany informacji i współpracy uzdrowisk, poprzez powołanie do życia dziewięciu partnerstw lokalnych i opracowanie dziewięciu lokalnych Strategii Zarządzania Zmianą Gospodarcza w Uzdrowiskach, rozwój rynku pracy poprzez wskazanie kierunków kształcenia i doskonalenia zawodowego oraz zwiększenie aktywności podmiotów w uzdrowiskach - z uwzględnieniem zmieniających się uwarunkowa-

\footnotetext{
${ }^{2}$ W latach 2002-2012 liczba państw reprezentowanych na Forum Ekonomicznym zwiększyła się z 4 do 61, a liczba korzystających z noclegów w Krynicy-Zdroju wzrosła z 12 tys. do 16,6 tys., tj. do 138\%, w tym turystów zagranicznych: z 2,4 tys. do 4,2 tys., tj. do $175 \%$.
} 
niach społeczno-gospodarczych - a także przygotowanie sposobów wdrażania strategii rozwoju w uzdrowiskach. Aktywne działania władz samorządowych Krynicy-Zdroju zmierzają do wykorzystania różnorodnych walorów uzdrowiska w celu podnoszenia konkurencyjności miasta i gminy. Wyrazem uznania dla licznych inicjatyw na rzecz rozwoju gospodarczego Krynicy-Zdroju jest nagroda dla najlepszej gminy małomiejskiej, którą w 2013 r. odebrał burmistrz miasta, dr Dariusz Reśko. Wyróżnienie to gmina otrzymała już trzeci raz z rzędu³.

Rodzi się zatem pytanie, czy różnego typu inicjatywy w zakresie budowania strategii rozwoju i zwiększania konkurencyjności uzdrowiska, podejmowane przez władze samorządowe, przyczyniają się do rozwoju społeczno-gospodarczego oraz korzystnego postrzegania Krynicy-Zdroju przez turystów i mieszkańców. W 2013 r. badaniami w Krynicy-Zdroju objęto 949 osób, zarówno turystów (538 osób), jak i mieszkańców miasta (411 osób) ${ }^{4}$. Autorzy zmierzali również do zweryfikowania, czy działania podejmowane przez władze samorządowe korespondują z oczekiwaniami i spostrzeżeniami gości uzdrowiska oraz jego mieszkańców. W analizie badań odniesiono się do inicjatyw organizowanych na terenie tylko miasta Krynica-Zdrój, a nie na obszarze całej gminy miejsko-wiejskiej.

\section{Uwarunkowania historyczne rozwoju Krynicy-Zdroju}

Kierunek rozwoju przestrzennego uzdrowiska wyznaczały przede wszystkim: dostęp do wód mineralnych, funkcje lecznicze i położenie w terenie górskim. Już na początku XIX w. powstał pierwszy plan zagospodarowania przestrzennego Krynicy, który zakładał budowę ujęć wód mineralnych, regulację rzek, rozbudowę dróg, rozdzielenie ruchu kołowego od ruchu pieszego w centrum miasta przez wybudowanie deptaka oraz założenie parku spacerowego w stylu angielskim na Górze Parkowej - z zachowanym do dziś układem ścieżek. Początek XIX w. to zaczątki budowy pierwszych obiektów uzdrowiskowych, które były przykładem architektury drewnianej. W 1804 r. powstał pierwszy budynek Łazienek Mineralnych, tzw. Mały Domek, natomiast w 1808 r. zbudowano pawilon pijalni nad Zdrojem Głównym, połączony z krytym deptakiem. Pijalnia, obok kabin kąpielowych, miała również pokoje dla kuracjuszy. Zainicjowano także proces butelkowania wody leczniczej i jej sprzedaży w obrębie kraju. Jednakże w późniejszym czasie niegospodarne zarządzanie Zakładem Zdrojowym doprowadziło do spadku znaczenia uzdrowiska i zahamowania jego rozwoju. Dopiero w latach 40. XIX w., po różnych perturbacjach i zmianach właścicieli, uzdrowisko wróciło w ręce władz skarbowych. Przełomowe wydarzenie w historii Krynicy miało miejsce w 1857 r., kiedy to prof. dr med. Józef Dietl wydał pracę naukową poświęconą kurortowi, propagując zdrowotne właściwości krynickich źródeł mineralnych. Na mocy postanowień komisji, która przybyła do zdrojowiska w 1856 r., w następnych latach wprowadzono wiele potrzebnych zmian odnoszących się do infrastruktury zakładu. Krynica zyskała uznanie arystokracji, polityków oraz artystów, stając się miejscem spotkań ważniejszych osobistości w kraju. Do rozwoju kurortu przyczyniło się również wybudowanie w 1876 r. linii kolei Nowy Sącz-Muszyna oraz rozbudowa drogi bitej do Muszyny w 1878 r. Wspomniane przedsięwzięcia ułatwiły gościom dojazd do Krynicy z całej Galicji. Rosnąca popularność ośrodka

\footnotetext{
${ }^{3}$ Metodą oceny poziomu rozwoju gminy jest syntetyczny wskaźnik rankingowy wyliczony w oparciu o 11 wskaźników mierzących potencjał, aktywność i wyniki osiągane przez gminę w sferze gospodarczej i społecznej. Ocenie poddawane są wszystkie gminy województwa małopolskiego z wyłączeniem miast na prawach powiatu: Krakowa, Nowego Sącza i Tarnowa.

${ }^{4}$ Badania ankietowe pod kierunkiem autorów przeprowadzili studenci II roku kierunku Gospodarka Przestrzenna z Instytutu Geografii Uniwersytetu Pedagogicznego im. Komisji Edukacji Narodowej w Krakowie.
} 
wpłynęła również na jego przemianę urbanistyczną. Z polecenia J. Dietla wycięto drzewa wokół źródeł i utworzono bulwary oraz kryty Deptak Szwajcarski. Wyrazem szybko rozwijającej się architektury drewnianej były nowe wille, m.in.: Węgierska Korona, Biała Róża, Witoldówka, Romanówka, Biały Orzeł. Cechami wspólnymi tych obiektów były kamienne podmurówki oraz bogato dekorowane ganki. W II poł. XIX w. wzrosła także liczba obiektów użyteczności publicznej. Powstały wówczas Stare Łazienki Mineralne, Łazienki Borowinowe oraz kościół na terenie Parku Zdrojowego. W 1883 r. ukończono budowę drewnianego teatru. W 1889 r. powstał najważniejszy i najokazalszy zarazem budynek uzdrowiskowy - Stary Dom Zdrojowy, uznawany za jeden z najpiękniejszych obiektów historycznych XIX-wiecznej Galicji. Pod koniec XIX stulecia i na początku XX w. wybudowano również nowe domy mieszkalne, przeprowadzono modernizację źródeł mineralnych, otworzono wodociąg wody słodkiej oraz powiększono Łazienki Mineralne.

Początek XX w. był dla Krynicy okresem istotnych przemian gospodarczych i kulturalnych. W latach 1907-1908 założono częściowe oświetlenie elektryczne oraz powstała międzymiastowa sieć telefoniczna. Kilka lat później uruchomiono węzeł kolejowy na trasie Krynica-Muszyna. W tym samym czasie wyznaczono granice administracyjne gminy Krynica-Zdrój, która została oddzielona od gminy Krynica-Wieś.

Po odzyskaniu niepodległości w Krynicy ruszyły prace nad odnowieniem dotychczasowej architektury oraz zainicjowano budowę nowych obiektów. Na potrzeby dalszego rozwoju uzdrowiska powołano Komisję Zdrojową, na której czele stanął inż. Leon Nowotarski. W latach 1924-1928 wybudowano Nowe Łazienki Mineralne, które były jednym z ważniejszych projektów okresu międzywojennego. Innym istotnym miejscem podkreślającym renomę Krynicy było sanatorium Lwigród zbudowane w 1929 r. Architektem, który podjął się zaprojektowania budynku, był Witold Minkiewicz. Warto nadmienić, że w tym czasie Lwigród, należał do najnowocześniejszych budynków sanatoryjnych w Polsce. W 1981 r. obiekt zamknięto, zaś dopiero w 2005 r. nowy nabywca dokonał jego kompleksowej renowacji. Innym ciekawym obiektem - oddanym do użytku latem 1939 r., był Nowy Dom Zdrojowy. W okresie 1818-1939 powstało wiele prywatnych hoteli i pensjonatów, m.in.: Patria, Rapsodia, Kasztelanka, a także gmach Poczty Polskiej i budynek PKO. W latach 20. zmodernizowano Park Zdrojowy przez poszerzenie ścieżek, posadzenie egzotycznych drzew oraz wykonanie przecinek odsłaniających widok. Na przełomie lat 20. i 30. u podnóża Góry Parkowej wzniesiono drewniany budynek zastępujący XIX-wieczne pawilony nad źródłem Jana i Józefa - obecną Pijalnię Jana i Józefa.

W czasie dwudziestolecia międzywojennego w Krynicy nastąpił wzmożony rozwój turystyki i sportu. W 1928 r. zbudowano stadion lodowy, a rok później - tor saneczkowy. W 1937 r., dzięki staraniom Polskiego Towarzystwa Tatrzańskiego, powstało schronisko na Jaworzynie Krynickiej. W 1937 r. ruszyła kolej na Górę Parkową. W okresie międzywojennym miasto zyskało rozgłos nie tylko na skalę krajową, lecz także europejską.

Wybuch II wojny światowej zahamował dynamiczny rozwój zdrojowiska. Część budynków zniszczono, inne zaś przebudowano (np. szkołę na kasyno). Po wojnie nastąpił proces nacjonalizacji uzdrowiska. Dzięki utworzeniu Funduszu Wczasów Pracowniczych w 1957 r., z krynickich sanatoriów masowo zaczęli korzystać ludzie z całego kraju, skierowani tu na leczenie. Wpłynęło to na zwiększenie liczby sanatoriów oraz ich bazy noclegowej. Jedną z pierwszych inwestycji tego typu było sanatorium Silesia zbudowane w 1963 r. Do innych wzniesionych w tym czasie sanatoriów należały: Budowlani (obecnie Panorama), Leśnik-Drzewiarz, Walcownik, Continental czy Pegaz. Ważniejszym obiektem, który powstał po wojnie, był budynek Nowej Pijalni z 1971 r. 
Okres powojenny to czas powstawania dużych osiedli mieszkaniowych dla personelu rozwijającego się uzdrowiska. Należały do nich osiedla: XX-lecia, Rewolucji Październikowej (obecne Źródlane) oraz Czarny Potok. Na obrzeżach miasta pojawiła się chaotyczna zabudowa jednorodzinna.

Przemiany ustrojowe lat 90 . XX w. spowodowały w Krynicy nasilenie procesów prywatyzacji i upadek wielu obiektów uzdrowiskowych. W głównej mierze przyczyną zahamowania rozwoju kurortu było zubożenie społeczeństwa oraz zamknięcie wielu zakładów pracy, które miały w Krynicy obiekty sanatoryjne i wypoczynkowe. Sytuacja ta wymusiła podjęcie działań prowadzących do podniesienia konkurencyjności miasta. W ramach przeprowadzonych inwestycji w 1997 r. ruszyła Kolej Gondolowa na Jaworzynę Krynicką, a rok później ukończono budowę hali widowiskowo-sportowej. Po 1989 r. powstało wiele obiektów wypoczynkowych. Należą do nich m.in.: hotele Krynica i Prezydent oraz hotel SPA dr Ireny Eris. Rozwojowi sektora usług turystycznych i rekreacyjnych (pensjonatów, restauracji, ośrodków narciarskiech) towarzyszy deprecjacja udziału usług leczniczych, stanowiących historycznie główny czynnik rozwoju uzdrowiska. Świadczyć może o tym fakt, że coraz większej liczbie turystów odwiedzających Krynicę-Zdrój towarzyszy stały spadek przeprowadzanych zabiegów leczniczych. Innym procesem zauważalnym współcześnie w funkcjonowaniu uzdrowiska jest rozwój usług turystycznych na terenach sąsiadujących z kurortem. Graniczące z Krynicą obszary wiejskie dotychczas w znikomym stopniu uczestniczyły w ofercie turystycznej. Jednakże od kilku lat na ich terenie następuje stały wzrost usług turystycznych: noclegowych, gastronomicznych i sportowych. Spośród miejscowości gminy Krynicy-Zdroju największy rozwój infrastruktury turystycznej odnotował sąsiadujący z miastem Tylicz, posiadający walory naturalne pod wieloma względami dorównujące uzdrowisku krynickiemu (Dorocki, 1999).

\section{Działania władz samorządowych na rzecz wzrostu konkurencyjności Krynicy-Zdroju}

Jak wspomniano powyżej, w latach transformacji gospodarczej sytuacja finansowa uzdrowisk w Polsce ulegała systematycznemu pogorszeniu i wielokrotnie podejmowano dyskusje na temat kierunku ich przekształceń. Rozmowy te nie przyniosły jednak zadowalających rozstrzygnięć. W 2003 r. utworzono Międzyresortowy Zespół do spraw Aktywizacji Społeczno-Gospodarczej Uzdrowisk, którego głównym zadaniem było przygotowanie wspólnej koncepcji prywatyzacji zakładów lecznictwa uzdrowiskowego (Reśko, 2010). Przewidywano, że realizacja zadań Zintegrowanego Programu Rozwoju Uzdrowisk, ze szczególnym uwzględnieniem usług turystycznych nastąpi w okresie od IV kwartału 2004 do końca 2005 r. Mimo że wypracowany przez Międzyresortowy Zespół do spraw Aktywizacji Społeczno-Gospodarczej Uzdrowisk program nie został w pełni wdrożony w życie, to okazał się on podstawą do dalszych działań prywatyzacyjnych sektora. Przeprowadzony proces komercjalizacji miał duży wpływ na procedurę zarządzania tymi podmiotami, ale nie doprowadził do wyraźnej poprawy ich kondycji. Uzależnienie spółek uzdrowiskowych prawie wyłącznie od jednego odbiorcy usług Narodowego Funduszu Zdrowia finansującego świadczenia według zasady non profit - nie pozwalało na uzyskanie znaczącej rentowności działalności uzdrowiskowej. Uniemożliwiało to finansowanie niezbędnych inwestycji z własnych środków oraz ograniczało finansowanie ze źródeł zewnętrznych. Przez wiele lat nie wypracowano strategii rozwoju sektora uzdrowiskowego w Polsce i nie wydaje się możliwe - w obecnych warunkach prawnych - dokapitalizowanie przedsiębiorstw uzdrowiskowych ze środków publicznych. Poza tym uzdrowiska niemające odpowiednich środków finansowych nie są w stanie sprostać wyzwaniom konkurencyjnym dużych koncernów i w konsekwencji tracą udział w rynku wód mineralnych. 
Podstawę dla działań podnoszących jakość życia i określających kierunki rozwoju społeczno-gospodarczego oraz zagospodarowania przestrzennego Krynicy-Zdroju stanowią liczne dokumenty, do których należą m.in.:

1. Strategia rozwoju zintegrowanego produktu turystycznego pt. „Perly Doliny Popradu”, opracowana dla sześciu gmin: Krynicy-Zdroju, Łabowej, Muszyny, Piwnicznej-Zdroju, Rytra, Starego Sacza, Polska Agencja Rozwoju Turystyki, Warszawa, wrzesień-grudzień 2003

2. Plan rozwoju lokalnego gminy Krynica-Zdrój, 2005.

3. Program rewitalizacji Krynicy-Zdroju na lata 2008-2013, 2009.

4. Strategia promocji Krynicy-Zdroju, 2011.

5. Inwentaryzacja obszaru uzdrowiskowego Krynica-Zdrój, (Instytut Turystyki w Krakowie Sp. z o.o.), 2011.

6. Strategia rozwoju miasta i gminy Krynica-Zdrój, maj-czerwiec 2013.

7. Strategia rozwoju i promocji małopolskiego produktu uzdrowiskowego na lata 2013-2018, Stowarzyszenie Gmin Uzdrowiskowych RP; publikacja współfinansowana przez Unię Europejską w ramach Małopolskiego Regionalnego Programu Operacyjnego na lata 2007$-2013^{5}$.

W działania mające na celu podnoszenie jakości kapitału ludzkiego i usprawnienie procesu administrowania miastem Krynica-Zdrój wpisuje się projekt Unowocześnienie funkcjonowania administracji samorządowej gminy Krynica-Zdrój realizowany przez Urząd Miejski w Krynicy-Zdroju od 1.01.2012 r. w ramach Programu Operacyjnego Kapitał Ludzki. Powyższe projekty, plany i strategie rozwoju odnoszą się nie tylko do samego miasta, lecz także do gminy miejsko-wiejskiej Krynica-Zdrój oraz innych gmin uzdrowiskowych województwa małopolskiego, tworząc w ten sposób spójną, całościową koncepcję rozwoju.

Dla zbudowania małopolskiego produktu uzdrowiskowego istotne znaczenie ma infrastruktura sportowo-turystyczna, do której w Krynicy-Zdrój należą m.in.: wyciągi narciarskie, lodowisko, baseny, korty tenisowe, tor saneczkowy, Krynicki Park Linowy oraz szlaki turystyczne i trasy rowerowe. Ważnym elementem budowania wizerunku uzdrowiska są także różne imprezy cykliczne, z których do najważniejszych należą:

1. Forum Ekonomiczne (wrzesień).

2. Europejski Festiwal im. Jana Kiepury (sierpień).

3. Małopolskie Spotkania Taneczne (czerwiec-lipiec).

4. Dni Wokalistyki Operowej (lipiec).

Gmina Krynica-Zdrój dysponuje bogatą bazą różnego typu obiektów noclegowych (304 obiekty), z których 17,1\% stanowią ośrodki wczasowe, 5,3\% to hotele, a 3,9\% - pensjonaty, oraz licznymi obiektami gastronomicznymi (74 placówki gastronomiczne), z których największy udział (44,6\%) stanowią bary i kawiarnie, a następnie restauracje oraz punkty gastronomiczne (po 14,9\%).

Należy podkreślić, że dużym atutem gminy jest także położenie przy granicy ze Słowacją, co wykorzystuje się w rozwoju współpracy transgranicznej przez realizację różnych projektów na tym obszarze. Znalazło to swoje odzwierciedlenie w realizacji projektu Rozwój regionu granicznego przez wspólna promocję i budowę Domu Polsko-Słowackiego w Czyrnej w latach 2006-2008 (Reśko, 2010). Projekt obejmował trzy miasta pogranicza polsko-słowackiego: Krynicę-Zdrój, Gorlice i Bardejov i skupił się na eksponowaniu podobnych walorów kulturowych i przyrodniczych tych terenów, a także kultywowaniu i ochronie ich

\footnotetext{
${ }^{5}$ www.sgurp.pl/images/Strategia\%20Rozwoju\%20i\%20Promocji\%20MPU.pdf.
} 
dziedzictwa kulturowego. Kolejnym przykładem współpracy transgranicznej na terenie gminy uzdrowiskowej jest kooperacja dwóch podmiotów gospodarczych prowadzących działalność na terenach przygranicznych. Partnerami przedsięwzięcia są dwa największe przedsiębiorstwa z terenu Krynicy-Zdroju - Uzdrowisko Krynica-Żegiestów S.A. oraz z miejscowości Wyżne Rużbachy (Vyšné Ružbachy) na terenie Słowacji - Uzdrowisko Wyżne Rużbachy. W celu aktywizacji współpracy transgrancznej na obszarze tym podejmowano również badania w zakresie przedsiębiorczości, przyjmujące za jej miarę decyzje o podjęciu działalności gospodarczej, oraz marketingowych działań biznesowych firm turystycznych, bazujących na położeniu przygranicznym. Wyniki tych badań wskazują jednakże na niski poziom aktywności przedsiębiorców, zarówno po stronie słowackiej, jak i polskiej, oraz konieczność intensyfikacji współpracy pomiędzy samorządami lokalnymi oraz organizacjami przedsiębiorców, a także kooperacji organizacji pozarządowych gmin pogranicza.

Do projektów oraz zadań inwestycyjnych o najwyższym prioryteciew latach 2007-2013 zgodnie z planem rozwoju lokalnego - zaliczono m.in. budowę :

1. sztucznego toru saneczkowo-bobslejowo-skeletonowego,

2. Regionalnego Centrum Rozrywki - etap II „Park Wodny”,

3. akwenu wodnego wraz z basenami na Czarnym Potoku,

4. wielopoziomowych parkingów,

5. bloków komunalnych.

Niestety, obecnie w planie zagospodarowania zrezygnowano z powyżej wspomnianego toru saneczkowo-bobslejowo-skeletonowego na Górze Parkowej przed prawomocnym rozstrzygnięciem toczących się postępowań sądowo-administracyjnych i jak dotąd nie znaleziono dla niego innej lokalizacji. Również inne projekty - w związku z niekorzystną sytuacją gospodarczą i światowym kryzysem gospodarczym - zostały wstrzymane (Zdon-Korzeniowska, Rachwał, 2011). Mimo to powzięte cele świadczą o przyjętym kierunku działań podejmowanych przez samorząd.

W celu aktywizacji gospodarczej przez rozwój produktu turystycznego warto byłoby realizować inne przedsięwzięcia infrastrukturalne oraz inicjatywy promocyjne, do których należą: 1. rewitalizacja i uatrakcyjnienie centrum miasta (budowa centrum Konferencyjnego Europa House, Parku Miniatur, kasyna, trasy fontann przy deptaku, alei żywych atrakcji, basenów geotermalnych, amfiteatru letniego)

2. utworzenie łemkowskiej doliny wakacyjnej,

3. budowa historycznego parku tematycznego (Wrota Narodów),

4. powstanie przygodowego parku tematycznego,

5. stworzenie krynickiego Centrum Urody,

6. stworzenie sportowego Parku Rodzinnego (w sąsiedztwie lodowiska),

7. budowa parku wodnego,

8. powstanie Międzynarodowej Stacji Turystycznej Krynicy,

9. promocja regionalnych potraw.

Jedną z postaw kreowania rozwoju w oparciu o usługi turystyczne jest regionalny produkt turystyczny (Zdon-Korzeniowska, 2009). Władze uzdrowiska dla Krynicy-Zdroju wyznaczyły cztery markowe produkty turystyczne? ${ }^{7}$ :

\footnotetext{
${ }^{6}$ www.wrotamalopolski.pl/NR/rdonlyres/2F0FE15D-DBCA-4E7C-B494-79C419189F62/911760/ Uch 115.pdf, s. 9.

${ }^{7}$ www.wrotamalopolski.pl/NR/rdonlyres/2F0FE15D-DBCA-4E7C-B494-79C419189F62/911760/ Uch_115.pdf.
} 
1. „Narty/zima” to produkt kształtowany w oparciu o wysoką pozycję Krynicy-Zdroju jako ośrodka narciarskiego. W tym wypadku decydujące znaczenie ma obecność kolejki i stoków na Jaworzynie Krynickiej, które są uznawane za jedne z najlepszych w Polsce, a ofertę tę uzupełnia szereg mniejszych wyciągów w różnych częściach miasta i gminy. Do zadań realizowanych w ramach tego produktu należą: Kolorowe Jarmarki Krynickie, organizacja lodowiska na deptaku, konkurs na lodowe rzeźby, Mistrzostwa Polski Branży Reklamowej w Narciarstwie, przygotowanie oferty dla dzieci - zima w Krynicy.

2. „MICE (Meetings - spotkania, Incentive - wyjazdy motywacyjne, Conferences - konferencje, Events - wydarzenia)" to produkt, którego najważniejszym wydarzeniem jest coroczne Forum Ekonomiczne, budujące markę konferencyjną miasta oraz wyznaczające kierunek jego rozwoju. Utrzymanie Forum w Krynicy wymaga wybudowania sali konferencyjnej na ponad tysiąc miejsc w ciągu kilku najbliższych lat, co umożliwi przyciągnięcie do miasta kolejnych dużych i prestiżowych imprez. W 2011 r. w Krynicy powstało Stowarzyszenie Convention Bureau, cyklicznie zbierające całą ofertę kongresową w mieście i promujące turystykę biznesową ${ }^{8}$.

3. „Uzdrowisko/spa” to produkt całoroczny, stosunkowo odporny na sezonowość warunków atmosferycznych. Krynica-Zdrój dysponuje powszechnie rozpoznawalną marką uzdrowiskową, choć obecnie słabnącą. Warto zatem na tej podstawie zbudować silną renomę zdrojowiska jako wiodącego ośrodka spa, m.in. przez wprowadzenie na rynek serii kosmetyków sugerujących związek z Krynicą-Zdrojem (np. produktów Ireny Eris).

4. „Lato w górach" to produkt zróżnicowany, skierowany głównie do rodzin z dziećmi, a także - w mniejszym zakresie - do grup dzieci i młodzieży szkolnej. Obejmuje on liczne zadania, m.in. pieszą pętlę krynicko-tylicką, Letni Salon Małopolski, budowę centrum dziedzictwa łemkowskiego, przygotowanie oferty dla dzieci - lato w Krynicy, akcję Krynica biega, imprezę Kwiecień plecień w Krynicy, weekend w Krynicy za pół ceny, Kolorowe Jarmarki Krynickie.

Strategiczna zasada produktów turystycznych Krynicy-Zdroju określona została w haśle: Krynica, tu jest życie!, ponieważ tu można dotknąć i kosztować smaku życia w różnych przejawach: zdrowia, zabawy, sztuki, jedzenia, rozrywki, sportu oraz ryzyka przygody. Strategia kładzie duży nacisk na uporządkowanie przestrzeni publicznej, usunięcie z niej „plastiku”, doświetlenie obiektów zabytkowych, zwłaszcza znajdujących się przy deptaku, rozwój dużej i małej architektury, zgodnie z charakterem miejsca. Warto podkreślić, że Krynica-Zdrój należy do nielicznych miast w Polsce, które mają zatwierdzony miejscowy plan zagospodarowania przestrzennego, regulujący możliwości przekształceń i kierunki inwestycyjne przestrzeni uzdrowiska. Ze względu na uzdrowiskowy charakter Krynicy-Zdroju i występowanie wód leczniczych, dodatkową trudnością w jego uchwaleniu była konieczność uzgodnienia planu z Okręgowym Urzędem Górniczym w Krakowie i Ministerstwem Zdrowia, co znacznie wydłużyło czas zatwierdzania tego dokumentu i ograniczyło możliwości inwestycyjne. Praca nad tzw. operatem uzdrowiskowym, mającym na celu udokumentowanie leczniczych właściwości wód mineralnych, stanu bazy sanatoryjnej oraz wyznaczenie strefy ochrony uzdrowiskowej, wiązała się z prowadzeniem długookresowych badań zanieczyszczeń powietrza, poziomu hałasu oraz czystości wód i źródeł, a także szczegółowej inwentaryzacji bazy sanatoryjno-leczniczej. Bardzo ważny dla planów zagospodarowania przestrzennego dokument: Statut Uzdrowiska Krynica-Zdrój przyjęto w oparciu o decyzję Rady Miejskiej uchwałą nr LII/364/2010 z dnia 21.06.2010 r.

\footnotetext{
${ }^{8}$ www.krynicaconvention.pl.
} 


\section{Ocena zagospodarowania Krynicy-Zdroju przez turystów}

W świetle przedstawionych działań, przed władzami samorządowymi w zakresie budowania strategii rozwoju i podnoszenia konkurencyjności uzdrowiska, zrodziło się pytanie, czy wysiłki te są dostrzegane przez turystów i znajdują odzwierciedlenie w ich postrzeganiu miasta.

Wśród badanych turystów największy udział stanowiły osoby w wieku 36-64 lat (44,2\%), podczas gdy udział ludności w grupie wiekowej 19-35 i powyżej 65 lat był zbliżony i wynosił odpowiednio: $25,7 \%$ i $25,8 \%$. Najwięcej respondentów miało wykształcenie wyższe (37,0\%), a następnie średnie (32,4\%), co łącznie stanowiło 68,4\% ogólnej liczby badanych. Pod względem statusu społeczno-zawodowego były to głównie osoby pracujące na umowę (40,1\%) oraz emeryci i renciści $(31,6 \%)$.

Według wyników ankiet turyści najczęściej przyjeżdżali do kurortu na 4-7 dni $(33,1 \%)$ i powyżej 14 dni (25,1\%). Najmniej osób wskazywało na jednodniowe pobyty (5\%), jednakże mogło to wynikać z faktu, że ankietę przeprowadzono w czasie tzw. długiego weekendu związanego ze świętem Bożego Ciała oraz w dni powszednie. Najbardziej popularną formą zakwaterowania były pensjonaty $(34,1 \%)$ i sanatoria $(24 \%)$, a następnie kwatery prywatne $(19,3 \%)$ i hotele $(17,1 \%)$. Pozostałe formy zakwaterowania wybierało zaledwie 5,4\% turystów (ryc. 1). Należy zauważyć, że współcześnie wiele sanatoriów - podobnie jak domy wczasowe - świadczy komercyjne usługi noclegowe.

Ryc. 1. Liczba dni pobytu turystów w Krynicy-Zdroju (A) i typ obiektu zakwaterowania (B)
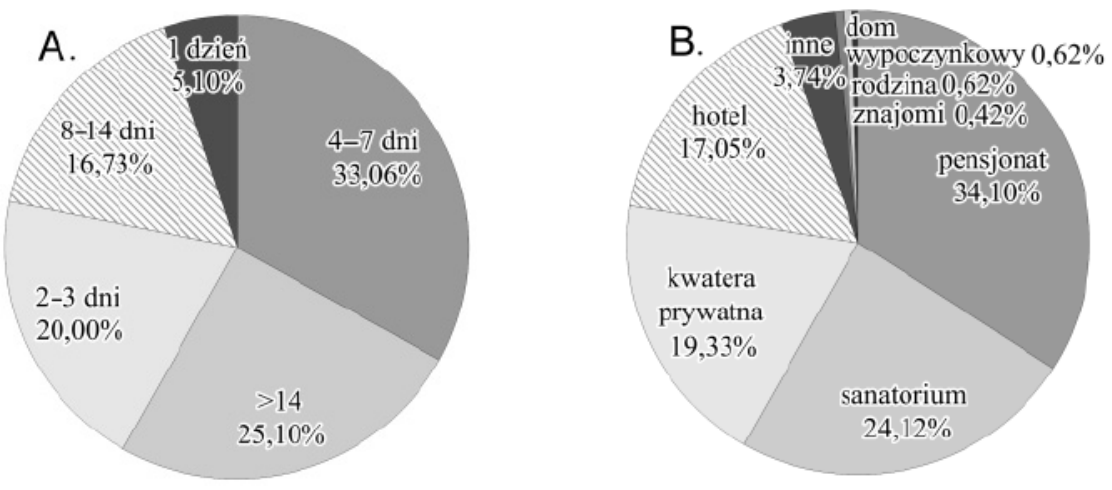

Źródło: opracowanie własne na podstawie badań ankietowych.

Analiza przyczyn przyjazdu wykazała, że były to najczęściej zalety wód zdrojowych $(35,6 \%)$ i walory krajobrazowe (35,0\%) (ryc. 2). Przytoczone walory wód zdrojowych nie odnoszą się jednak do ich leczniczych wartości, a bardziej do atrakcji, jaką wody te stanowią dla gości kurortu, i dużej renomy samego uzdrowiska. Spośród ankietowanych tylko 7,1\% jako przyczynę przyjazdu zadeklarowało problemy zdrowotne. Innymi czynnikami wpływającymi na przyjazdy do kurortu były imprezy kulturalne i turystyczne $(5,6 \%)$ oraz odwiedziny u znajomych i rodziny $(5,3 \%)$. Główne źródło informacji dla turystów stanowiła rodzina lub znajomi $(35,0 \%)$ $\mathrm{i}$ internet $(33,2 \%)$.

Przestawione dane, odnoszące się do wizerunku statystycznego gościa kurortu, wskazują na zmianę funkcji Krynicy-Zdroju z ośrodka leczniczego na miejsce rekreacji i wypoczynku. Świadczy o tym również znikomy odsetek respondentów, którzy korzystali ze świadczeń zdrowotnych w uzdrowisku, miejsce zakwaterowania oraz wiek turystów. 
Ryc. 2. Główne przyczyny przyjazdu do Krynicy-Zdroju (A) i źródła informacji o mieście (B)
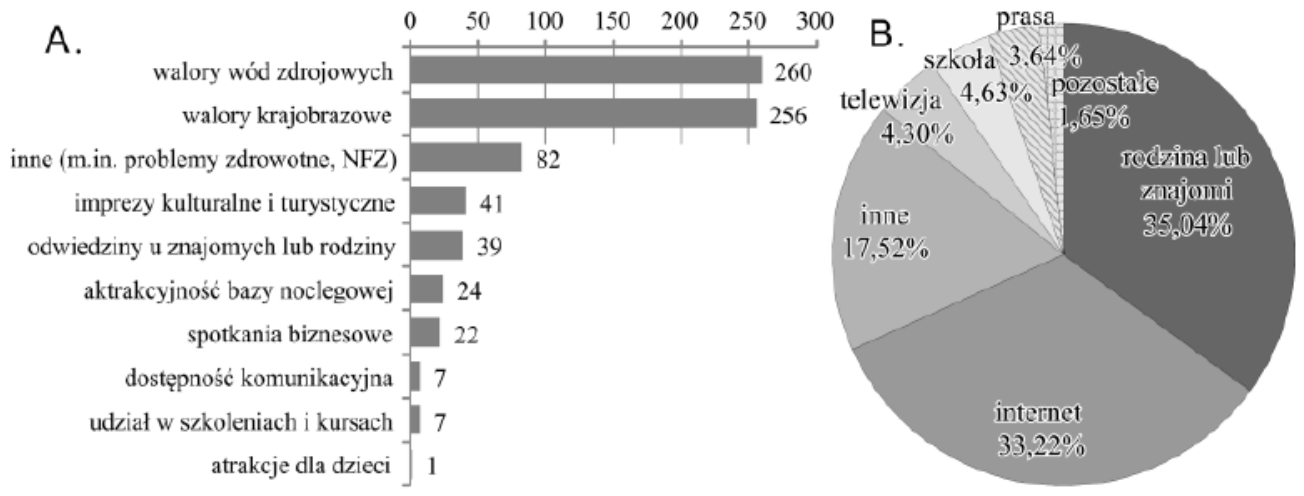

Źródło: opracowanie własne na podstawie badań ankietowych.

Ryc. 3. Ocena ogólnego obrazu Krynicy-Zdroju (A) i zainteresowanie ponownym przyjazdem do miejscowości (B)

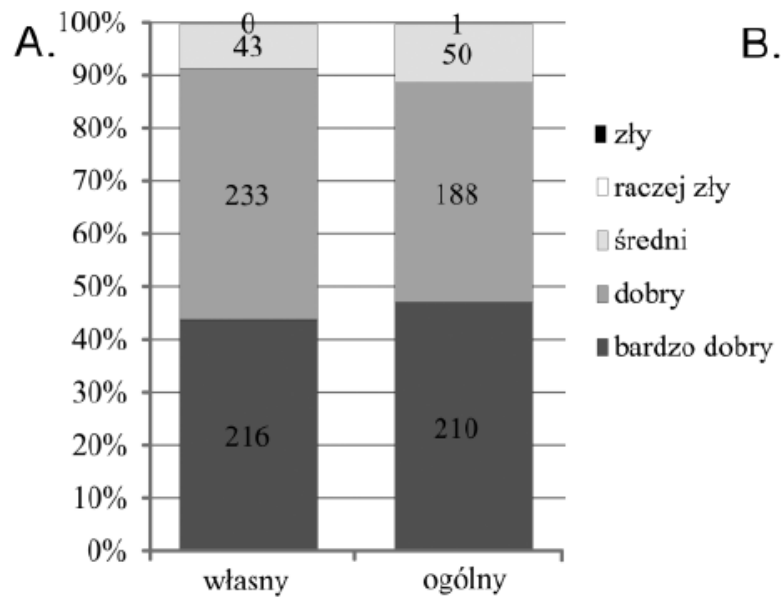

\begin{tabular}{|l|r|}
\hline nie & $\mathbf{2 2}$ \\
\hline raz wystarczy & $50 \%$ \\
\hline tłok, dużo ludzi & $30 \%$ \\
\hline nudno, nie ma co robić & $20 \%$ \\
\hline tak, ponieważ.. & $\mathbf{2 6 9}$ \\
\hline powietrze & $22,9 \%$ \\
\hline walory krajobrazowe & $20,0 \%$ \\
\hline odpoczynek & $14,3 \%$ \\
\hline podoba mi się & $11,4 \%$ \\
\hline klimat & $8,6 \%$ \\
\hline wody zdrojowe & $5,7 \%$ \\
\hline miejsce atrakcyjne & $5,7 \%$ \\
\hline jest dobry stok & $2,9 \%$ \\
\hline uprzejmi ludzie & $2,9 \%$ \\
\hline podoba mi się region & $2,9 \%$ \\
\hline atrakcje & $2,9 \%$ \\
\hline tak, ale.. & $\mathbf{3 5}$ \\
\hline
\end{tabular}

Źródło: opracowanie własne na podstawie badań ankietowych.

Turyści odwiedzający Krynicę-Zdrój pochodzili ze wszystkich województw w Polsce, poza województwem zachodniopomorskim, z którego nie pochodziła żadna badana osoba. Największą liczbę turystów odwiedzających kurort stanowili mieszkańcy województwa małopolskiego - 33,5\%, a następnie województw: śląskiego: 17,7\%, mazowieckiego: 10,4\% i świętokrzyskiego: 9,2\%. Łącznie z tych czterech województw pochodziło 70,7\% ogólnej liczby badanych turystów. Wpływ na przedstawioną strukturę pochodzenia gości uzdrowiska miała bliskość komunikacyjna w wypadku Małopolski, natomiast w sytuacji województwa śląskiego fakt, że jego mieszkańcy - częściej narażeni na choroby płuc - kierowani są przez lekarzy do sanatoriów, natomiast turyści z Mazowsza mają długą tradycję dotyczącą wypoczynku w Krynicy-Zdroju, sięgającą czasów międzywojennych. Największy udział w ogólnej liczbie badanych turystów stanowiły osoby pochodzące z Krakowa (12,7\%), a następnie z Kielc 
i Warszawy (po 4,2\%), Tarnowa (3,6\%) oraz Lublina, Radomia i Wrocławia (po 3,0\%). Łącznie zatem z tych siedmiu miast pochodziło 33,9\% badanych turystów.

W badaniach ankietowych zapytano turystów o opinię na temat bezpieczeństwa, czystości i zagospodarowania Krynicy-Zdroju. Wyniki analiz wskazują, że bardzo dobry i dobry obraz miejscowości miało aż 89,3\% turystów, a średni - 8,3\% (ryc. 3). Należy podkreślić, że żadna z osób nie wskazała, że obraz ten jest zły lub bardzo zły i aż 82,5\% badanych chciałoby przyjechać ponownie do miejscowości. Podobnie bardzo dobrą i dobrą ocenę w zakresie poziomu bezpieczeństwa wskazało aż 95,6\% ogólnej liczby respondentów, czystości miejscowości 93,9\%, a zagospodarowania miejscowości - 90,2\% (ryc. 4).

Ryc. 4. Opinia turystów na temat warunków wyposażenia oraz poziomu bezpieczeństwa, czystości i zakwaterowania w Krynicy-Zdroju

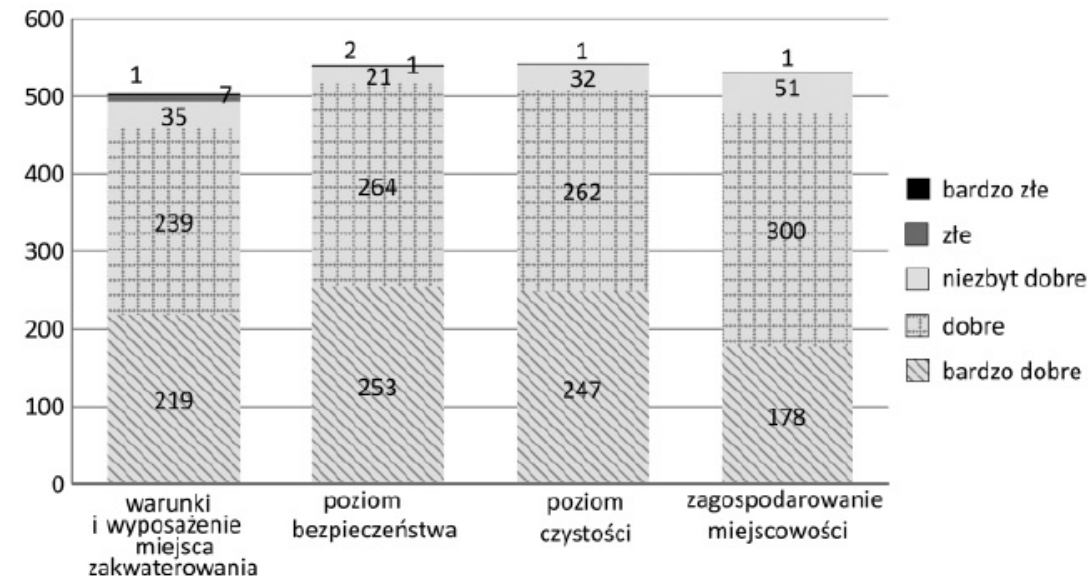

Źródło: opracowanie własne na podstawie badań ankietowych.

Oceniając warunki i wyposażenie miejsca zakwaterowania, aż 91,4\% badanych wyraziło bardzo dobrą i dobrą opinię na ten temat, a zaledwie 1,6\% turystów określiło te warunki jako złe lub bardzo złe. Analizując wyposażenie obiektów zakwaterowania, można stwierdzić, że $84 \%$ było zaopatrzonych w odrębną łazienkę, a ok. 2/3 miało parking, balkon i dostęp do internetu. Nieco mniej obiektów dysponowało własną stołówką i ogródkiem (67,7\%) lub placem zieleni (66,2\%) (ryc. 5). Znacznie mniej miejsc zakwaterowania miało plac zabaw dla dzieci (34,0\%), salę konferencyjną (24,9\%), basen (17,5\%), siłownię (16,4\%) i klimatyzację (11,3\%).

Pomimo tak dobrych ocen, turyści spostrzegli, że należałoby przeprowadzić pewne zmiany w zagospodarowaniu miejscowości i najczęściej zwracano uwagę na niedostatek miejsc parkingowych oraz koszów na śmieci, źle oznakowane szlaki turystyczne, ubogą publiczną infrastrukturę higieniczną, brak miejsc zabaw dla dzieci i młodzieży oraz kawiarenek.

Następnie ocenie poddany został poziom zaspokojenia potrzeb turystów w zakresie różnych elementów infrastruktury (ryc. 6). We wszystkich wartościowanych dziedzinach dominowała nota dobra, poza zabiegami uzdrowiskowymi, które w 44,1\% przypadków oceniono na poziomie bardzo dobrym, a na dobrym w 19,2\% wskazań. Najwięcej ocen bardzo dobrych i dobrych otrzymała dostępność obiektów handlu spożywczego i handlu innymi artykułami. Największa liczba turystów określiła jako dobrą dostępność handlu spożywczego (45\% wskazań) i handlu innymi artykułami (44\%), a jako bardzo dobrą odpowiednio: 38,2\% i 24,6\%. Następnie najwyższe - bardzo dobre i dobre - stopnie otrzymały szlaki turystyczne $(78,5 \%)$, obiekty 
kulturalne $(72 \%)$, kawiarnie $(71,8 \%)$ oraz restauracje $(71,3 \%)$. Najgorszy poziom zadowolenia turystów stwierdzono w zakresie dostępności parkingów, na których zły i bardzo zły stan wskazało 28,4\% wczasowiczów. Stosunkowo wysoki poziom niezadowolenia wyrażono w wypadku dyskotek (10,5\%) i komunikacji (10,1\%).

Ryc. 5. Opinia turystów na temat warunków i wyposażenia miejsca zakwaterowania (A) oraz elementy zagospodarowania Krynicy-Zdroju, które powinny ulec poprawie (B)

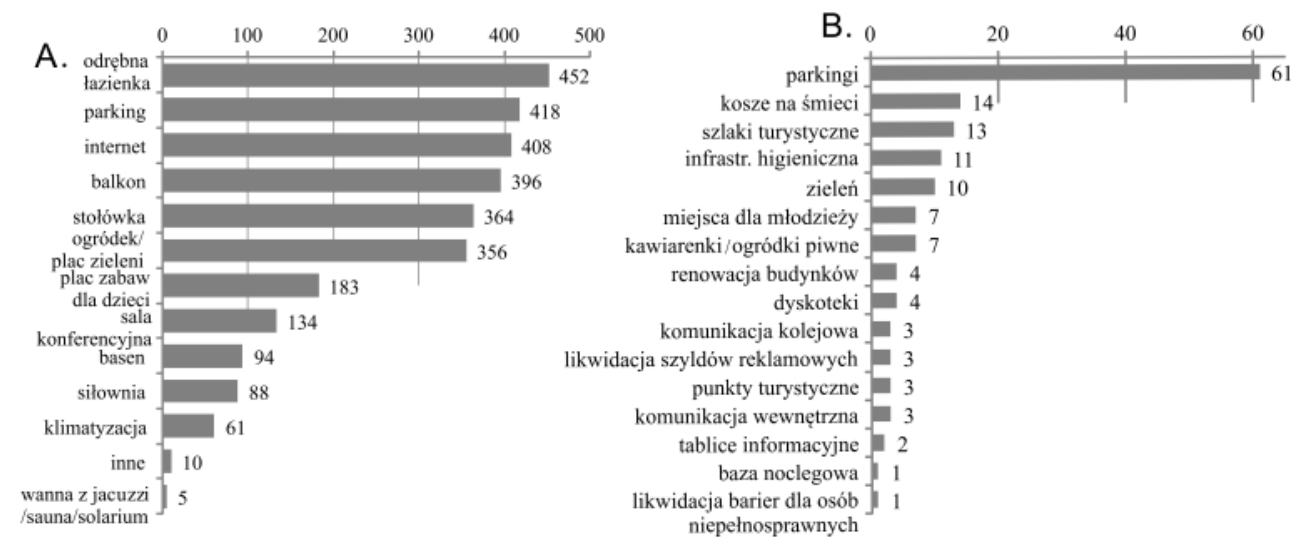

Źródło: opracowanie własne na podstawie badań ankietowych.

Ryc. 6. Ocena poziomu zaspokojenia potrzeb turystów w zakresie różnych elementów infrastruktury w Krynicy-Zdroju

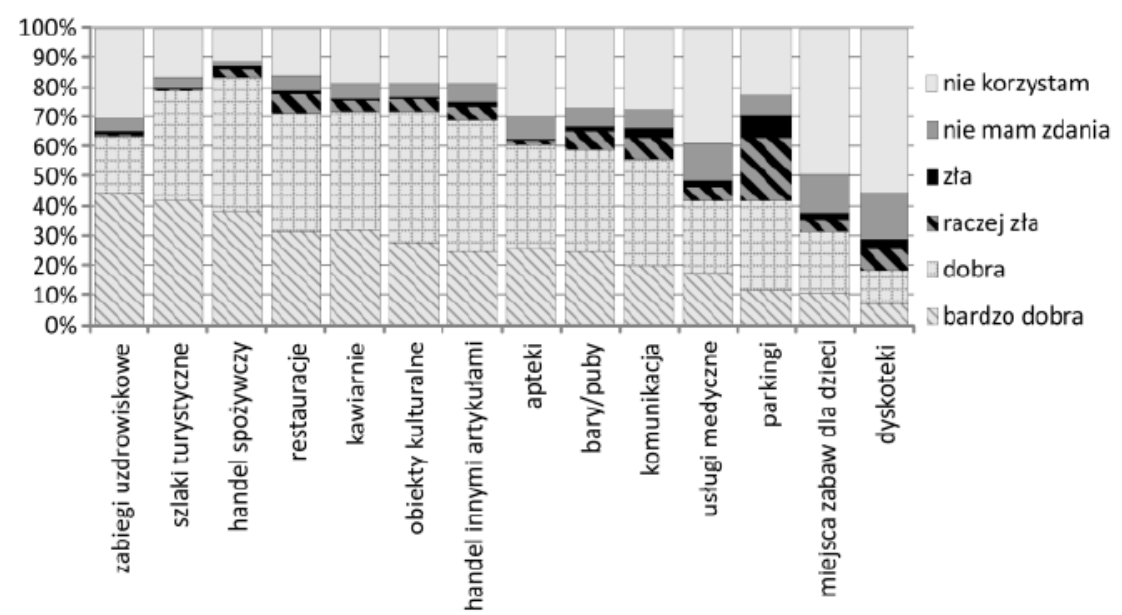

Źródło: opracowanie własne na podstawie badań ankietowych.

Podsumowując, stwierdza się, że Krynica-Zdrój jest postrzegana jako atrakcyjne miejsce do wypoczynku dla turystów przybywających z całego kraju i dla osób w różnym wieku. Ogólnie turyści byli zadowoleni z pobytu w mieście, z różnorodnej oferty uzdrowiskowej i rekreacyjnej oraz dobrze oceniali stan zagospodarowania, bezpieczeństwa i czystości kurortu. 


\section{Ocena zagospodarowania i jakości życia w Krynicy-Zdroju przez mieszkańców}

Następnie badaniami określającymi poziom zadowolenia z zagospodarowania i jakości życia w Krynicy-Zdroju objęto jej mieszkańców. Największy udział stanowiły osoby wieku 36-64 lat - 39,7\%, podczas gdy udział w grupie wiekowej 19-35 lat wyniósł 37,5\%. Udział w badaniu osób najmłodszych - do 18 roku życia - i najstarszych - powyżej 65 lat - był zbliżony, dając odpowiednio wynik: 11,7\% i 11,2\%.

Spośród respondentów najwięcej z osób miało wykształcenie średnie (40\%) i wyższe (19,8\%). Łącznie osoby z tych dwóch grup stanowiły 69,8\% ogólnej liczby badanych mieszkańców. Natomiast wykształcenie zawodowe wykazało 18,3\%, a podstawowe $-11 \%$ ankietowanych.

Pod względem statusu społeczno-zawodowego w badaniu uczestniczyły głównie osoby pracujące $(52,7 \%)$ oraz emeryci i renciści (13,9\%). Uczniowie i studenci stanowili 19,6\% badanych. Najmniejszy odsetek stanowiły osoby prowadzące własną działalność $8,8 \%$ oraz bezrobotni - 4,4\%. Spośród ankietowanych $69 \%$ stanowiły osoby mieszkające w Krynicy-Zdroju od urodzenia. W pozostałych wypadkach najważniejszą przyczyną zamieszkania w kurorcie było zawarcie małżeństwa $(61,2 \%)$ i praca $(17,9 \%)$. Respondenci w 68,5\% mieszkali w domach, a tylko $31,5 \%$ w mieszkaniach - w tym głównie własnościowych $(83,8 \%)$. Stan wyposażenia miejsca zamieszkania wskazuje, że powszechnym jest posiadanie łazienki, telefonu, elektryczności i wodociągu. Jednakże duża część respondentów korzysta dalej z ogrzewania węglem oraz nie jest podłączona do miejskiej kanalizacji i instalacji gazowej, co może niekorzystnie wpływać na stan środowiska naturalnego uzdrowiska (ryc. 7).

Ryc. 7. Stan wyposażenia miejsca zamieszkania mieszkańców Krynicy-Zdroju

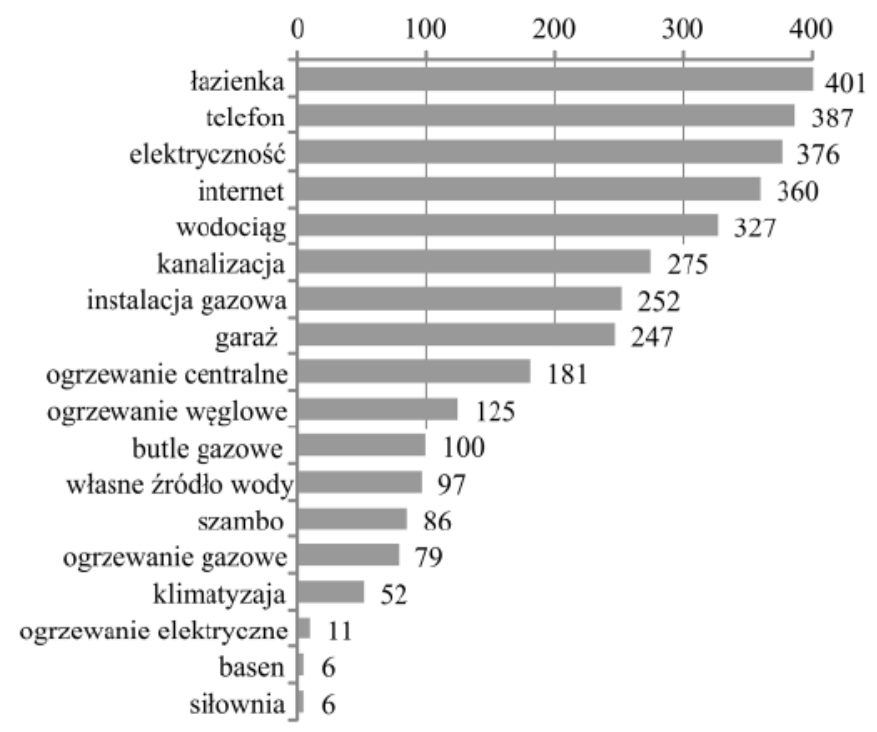

Źródło: opracowanie własne na podstawie badań ankietowych.

Ogólny obraz miejscowości, jaki mają mieszkańcy, jest dobry, na co wskazało 40,5\% ankietowanych, jednakże 43,6\% uznało, że mógłby być lepszy. Znikomy udział (0,3\%) stanowili mieszkańcy uważający, że obraz Krynicy-Zdroju jest raczej zły. Respondenci zauważyli, że opinie o dobrym obrazie miasta podzielają też inne osoby (58\%), a że obraz Krynicy mógłby być lepszy w opinii innych, uważa tylko $21 \%$ badanych. 
Zadowolenie z życia w mieście potwierdza fakt, że 62,2\% osób nie chciałoby się przeprowadzić gdzie indziej (ryc. 8). Osoby, które pragnęłyby opuścić Krynicę-Zdrój, najchętniej udałyby się do dużego miasta - 19,5\%, poza miasto - 9,8\% i za granicę - $8,5 \%$ badanych.

Ryc. 8. Opinia na temat chęci zmiany miejsca zamieszkania (A) i oceny jakości życia (B)
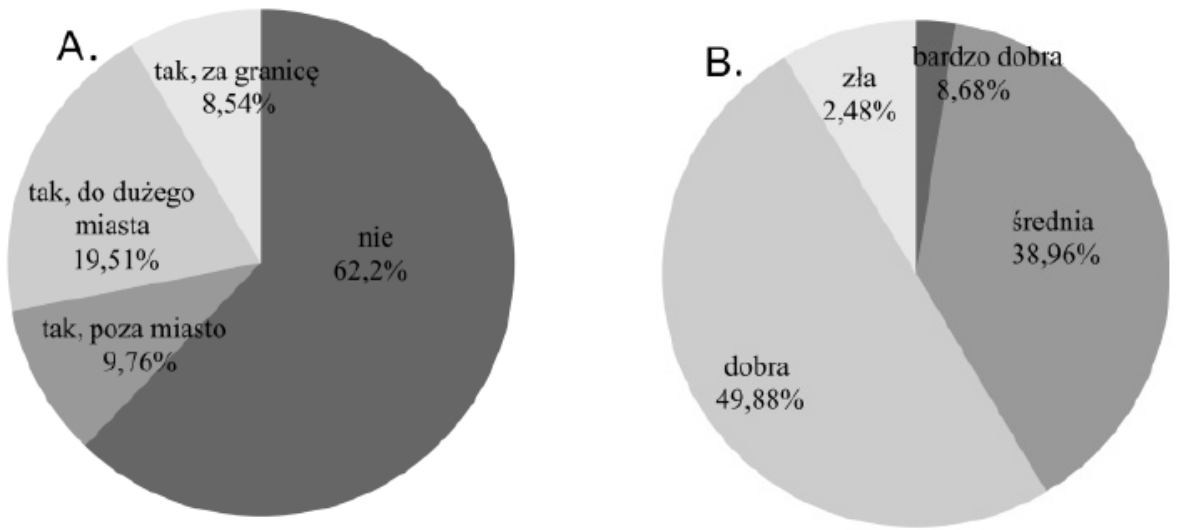

Źródło: opracowanie własne na podstawie badań ankietowych.

Mieszkańcy miasta, ustosunkowując się do ogólnej jakość swojego życia, w większości ocenili ją jako dobrą (49,9\%) i średnią (39\%) (ryc. 9). Bardzo dobrze swoją jakość życia oceniło 8,7\% badanych, a jako złą zaledwie 2,5\%. Wysoki standard życia wydają się ponadto potwierdzać odpowiedzi mieszkańców, że musza oszczędzać, ale stać ich na wszystko, którą udzieliło 52,7\% i stać nas na wszystko, co chcemy - 13,6\% ankietowanych.

Ryc. 9. Samoocena sytuacji materialnej mieszkańców (A) i ogólny obraz miejscowości (B)
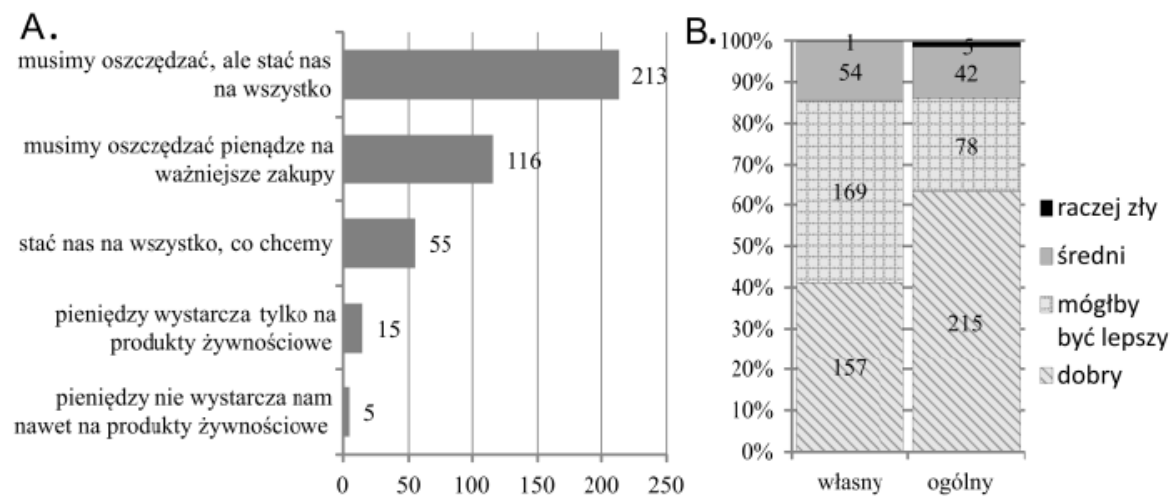

Źródło: opracowanie własne na podstawie badań ankietowych.

Mieszkańcy miasta, odpowiadając na pytania dotyczące zadowolenia z różnych dziedzin życia, najczęściej we wszystkich z nich podawali odpowiedzi zadowolony i raczej zadowolony (ryc. 10). Ankietowani są najbardziej zadowoleni ze stanu zdrowia, mieszkania, poczucia bezpieczeństwa i czystości miejscowości. Natomiast najmniejsze zadowolenie spowodowane jest ilością wolnego czasu, sąsiadami i pracą. Można zatem przypuszczać, że warunki życia dla większości mieszkańców Krynicy-Zdroju są zadowalające. 
Ryc. 10. Poziom zadowolenia z różnych dziedzin życia mieszkańców Krynicy-Zdroju

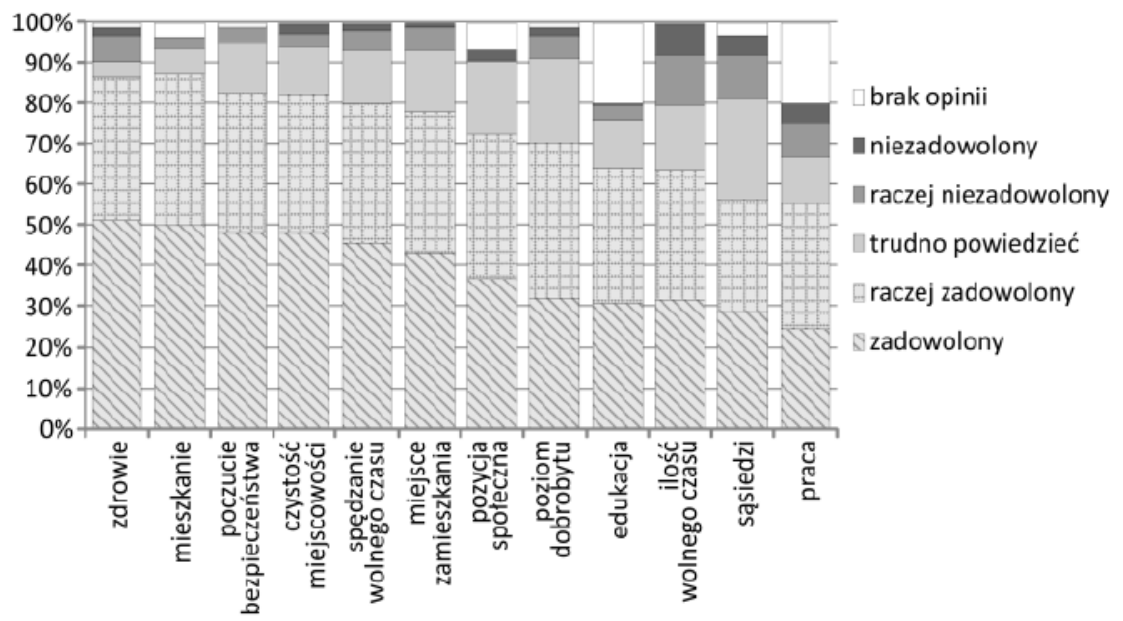

Źródło: opracowanie własne na podstawie badań ankietowych.

Mieszkańcy miasta, odnosząc się do zadowolenia z infrastruktury społecznej i technicznej Krynicy-Zdroju, najlepiej ocenili dostępność i jakość handlu spożywczego, aptek i handlu artykułami przemysłowymi (ryc. 11). Stosunkowo wysoki udział stanowiły wskazania jako raczej złe i złe w odniesieniu do administracji 23,4\%, publicznego transportu $(19,4 \%)$ i usług medycznych $(17,7 \%)$.

Ryc. 11. Poziom zadowolenia z różnych dziedzin życia mieszkańców Krynicy-Zdroju

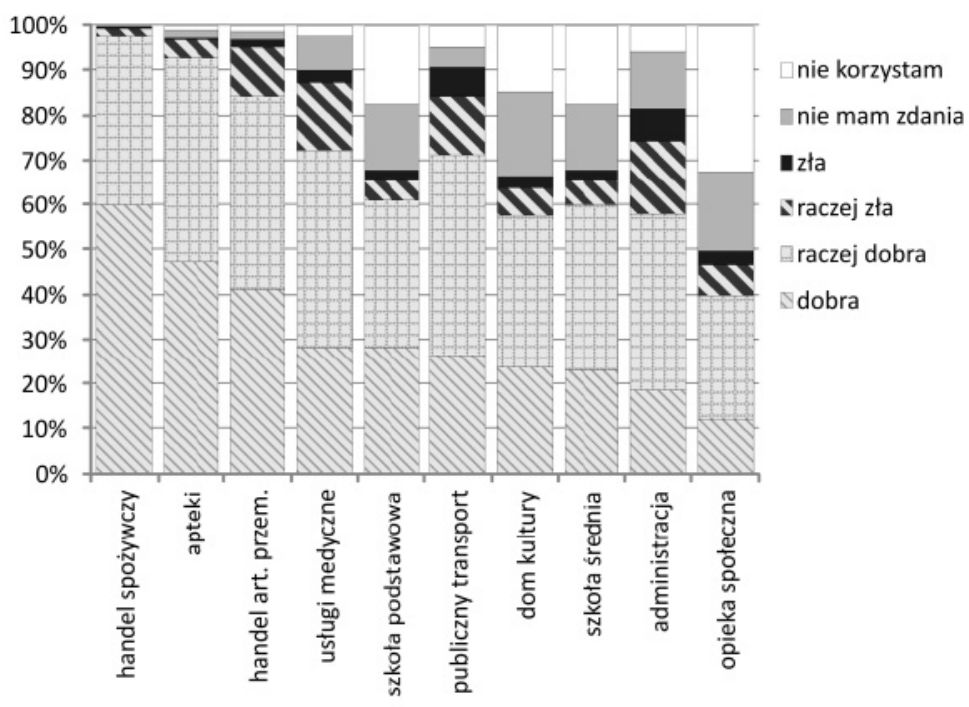

Źródło: opracowanie własne na podstawie badań ankietowych. 
Podsumowując, stwierdza się, że mieszkańcy Krynicy-Zdroju są zadowoleni z życia w mieście, sytuacji materialnej, z dostępności różnego rodzaju usług oraz stanu zagospodarowania, poziomu bezpieczeństwa i czystości miasta. Zwracali oni jednak uwagę na trudności w zakresie komunikacji i dostępności parkingów oraz wyrażali niezadowolenie z działalności władz samorządowych w tym zakresie. Potwierdza to fakt, że komunikacja - ze względu na położenie Krynicy-Zdroju i topografię terenu - jest jednym z największych problemów uzdrowiska. Studium komunikacyjne miasta, które wskazywało możliwe do poprowadzenia korytarze przestrzenne dla lokalizacji dróg, ulic i ich wzajemne powiązania, miało być ważnym elementem planu zagospodarowania, jednakże nie zostało ono zrealizowane, układu komunikacyjnego nie poddano szerokim konsultacjom społecznym. Niezadowolenie mieszkańców miasta dotyczy także wprowadzenia zapisów do ustaleń planu zagospodarowania, które nakładają na mieszkańców i inwestorów dodatkowe rygory podnoszące koszty inwestycyjne.

\section{Zakończenie}

Zasadniczym celem władz lokalnych Krynicy-Zdroju jest kształtowanie optymalnych warunków zarówno dla życia i działalności mieszkańców miasta, jak i odwiedzających go turystów. Jak zauważa Więcław-Michniewska (2011), Krynica-Zdrój należy do miast o najwyższym stopniu działań władz lokalnych na rzecz promocji i rozwoju turystyki, jako czynnika stymulującego wzrost społeczno-gospodarczy. Prowadzone przez autorkę analizy porównawcze strategii polskich miast karpackich w zakresie znaczenia w polityce miejskiej funkcji turystycznej, zakresu informacyjnego, jakości stron internetowych oraz rozróżnienia w strategiach rozwoju możliwości intensyfikacji funkcji turystycznej w oparciu o zasoby miasta i gminy wskazują, że Krynica-Zdrój zajmuje w tym zakresie najwyższą pozycję. Należy jednak podkreślić, że ważnym czynnikiem determinującym rozwój gospodarczy miasta jest położenie topograficzne, które warunkuje możliwości zagospodarowania przestrzennego i związane z tym koszty inwestycji. Nawiązuje to do zaobserwowanej prawidłowości, że im korzystniejsze położenie miast w ujęciu osadniczym, tym niższe potencjalne możliwości rozwoju funkcji turystycznej.

Jak przyjmują Krupa, Soliński i Bajorek (2011), turystyka uzdrowiskowa, aby mogła być konkurencyjna, musi mieć wielofunkcyjny charakter działalności, oparty zarówno na funkcji uzdrowiskowej, jak i turystycznej (rekreacyjnej i wypoczynkowej), oraz mieć w swej ofercie innowacyjny produkt uzdrowiskowy. Turystyka uzdrowiskowa może być czynnikiem pobudzania rozwoju gospodarczego, poprawy stanu zdrowia i profilaktyki gości uzdrowiskowych, a także przyczynić się do rozwoju nowych form turystyki, miejsc pracy i poprawy jakości życia mieszkańców. W świetle przedstawionych rozważań wydaje się, że postulat ten jest skutecznie realizowany w Krynicy-Zdroju i przekształcenia społeczno-gospodarcze i przestrzenne miasta zmierzają we właściwym kierunku, odpowiadając na współczesne wyzwania rozwoju cywilizacyjnego oraz godząc potrzeby zarówno mieszkańców, jak i turystów odwiedzających uzdrowisko. 


\section{Literatura \\ References}

Dorocki, S. (1999). Monografia społeczno-gospodarcza gminy Krynica. Krynica: Urząd Gminy Uzdrowiskowej.

Dorocki, S., Brzegowy, P. (2013). Impact of natural resources on the development of spa industry in Krynica-Zdroj. W: In proceeding of: 13th SGEM GeoConference on Ecology, Economics, Education And Legislation, SGEM 2013 Conference Proceedings, At Albena, Bulgaria, Vol. II, 309-316.

Dryglas, D. (2009). Innowacje produktowe turystyki uzdrowiskowej. W: J. Golba, K. Rymarczyk-Wajda (red.), Innowacyjne kierunki rozwoju turystyki uzdrowiskowej i lecznictwa uzdrowiskowego: XVIII Kongres Uzdrowisk Polskich. Krynica-Zdrój: Stowarzyszenie Gmin Uzdrowiskowych RP, 167-174.

Golba, J. (2002). Aktywizacja społeczno-gospodarcza gmin uzdrowiskowych jako podstawa ich rozwoju. W: XI Kongres Uzdrowisk Polskich-Materiaty Konferencyjne. Krynica-Zdrój: Stowarzyszenie Gmin Uzdrowiskowych RP, 13-24.

Kaczmarska, E. (2002). Uzdrowisko i jego przestrzeń społeczna. Wybrane zagadnienia przestrzenne polskich uzdrowisk karpackich w aspekcie integracji europejskiej. Zeszyty Naukowe Politechniki Krakowskiej, seria: architektura. 47.

Kłos, A. (2011). Rola przedsiębiorczości władz i mieszkańców gminy Horyniec-Zdrój w aktywizacji gospodarczej regionu. Przedsiębiorczość - Edukacja. 7, 197-206.

Krupa, J., Soliński, T., Bajorek, M. (2011). Determinanty rozwoju turystyki zrównoważonej i zdrowotnej na terenie uzdrowisk - kreowanie jakości produktu turystycznego i uzdrowiskowego. W: T. Soliński, J. Krupa (red.), Uwarunkowania innowacyjnego rozwoju uzdrowisk. Rzeszów: Instytut Gospodarki Wyższej Szkoły Informatyki i Zarządzania, 21-56.

Krupa, J., Wołowiec, T. (2010). Uzdrowiska Polski Wschodniej wobec wyzwań rozwojowych - turystyka zrównoważona. W: J. Hermaniuk, J. Krupa (red.), Współczesne trendy funkcjonowania uzdrowiskklastering. Rzeszów: Instytut Gospodarki Wyższej Szkoły Informatyki i Zarządzania, 7-36.

Lasak, G. (2010). Uzdrowiska a rozwój lokalny i regionalny - Szanse i bariery na przykładzie uzdrowisk świętokrzyskich. W: J. Hermaniuk, J. Krupa (red.) Współczesne trendy funkcjonowania uzdrowiskklastering. Rzeszów: Instytut Gospodarki Wyższej Szkoły Informatyki i Zarządzania, 105-124.

Lewandowska, A. (2005). Działalność marketingowa polskich uzdrowisk na konkurencyjnym rynku. Prace Naukowe Akademii Ekonomicznej we Wroctawiu. 1074, 154-161.

Reśko, D. (2010). Problematyka funkcjonowania sektora uzdrowiskowego w Polsce - wybrane aspekty. W: M. Reichel (red.), Transgraniczna turystyka ekologiczna jako szansa rozwoju Sądecczyzny. Sadeckie Zeszyty Naukowe. tom I. Nowy Sącz: Starostwo Powiatowe, 125-139.

Reśko, D. (2010). Rozwój polsko-słowackiej współpracy transgranicznej na przykładzie gminy Krynica-Zdrój. W: M. Reichel (red.), Transgraniczna turystyka ekologiczna jako szansa rozwoju Sądecczyzny. Saceckie Zeszyty Naukowe. tom I. Nowy Sącz: Starostwo Powiatowe, 28-48.

Więcław-Michniewska, J. (2011). Wybrane kierunki rozwoju funkcji turystycznej miast Karpat Polskich, Instytut Geografii i Gospodarki Przestrzennej Uniwersytetu Jagiellońskiego, Prace Geograficzne, 125, 179-196.

Wołowiec T., Reśko D. (2012). Strategia rozwoju gminy jako narzędzie zarządzania zmianą gospodarczą. Zeszyty Naukowe WSEI, seria: ekonomia, 5(2), 61-89.

Zaręba, K. (2012). Zrównoważony rozwój warunkiem zabezpieczenia funkcji rekreacyjnych uzdrowisk. Inżynieria Ekologiczna, 30, 206-218.

Zdon-Korzeniowska, M. (2009). Jak ksztattować regionalne produkty turystyczne?. Kraków: Wydawnictwo Uniwersytetu Jagiellońskiego.

Zdon-Korzeniowska, M., Rachwał, T. (2011). Turystyka w warunkach światowego kryzysu gospodarczego. Prace Komisji Geografii Przemystu Polskiego Towarzystwa Geograficznego, 18, 116-128. 
Monika Borowiec, doktor nauk o Ziemi w zakresie geografii, adiunkt w Instytucie Geografii Uniwersytetu Pedagogicznego im. KEN w Krakowie. Zainteresowania badawcze autorki koncentrują się wokół problematyki gospodarki opartej na wiedzy, roli szkolnictwa wyższego i ośrodków naukowych w procesie kształtowania społeczeństwa informacyjnego, procesów transformacji społeczno-gospodarczej, ze szczególnym uwzględnieniem procesów globalizacji i integracji europejskiej, a także problematyki przedsiębiorczości.

Monika Borowiec, PhD in Earth Sciences, Geography, Adiunkt (Associate Professor) at Pedagogical University of Cracow, Institute of Geography.

Monika Borowiec interests are concentrated on the knowledge-based economy, the role of higher education and academic centers in the process of socio-economic transformation, and the processes of globalization and European integration.

Sławomir Dorocki, dr, absolwent studiów z zakresu geografii społeczno-ekonomicznej Uniwersytetu Pedagogicznego im. KEN w Krakowie, doktor nauk humanistycznych w dyscyplinie historia (Instytut Europeistyki - Uniwersytet Jagielloński). Adiunkt w Instytucie Geografii Uniwersytetu Pedagogicznego im. Komisji Edukacji Narodowej w Krakowie. Zainteresowania badawcze autora skupiają się wokół problematyki regionów i procesów regionalizacji społeczno-gospodarczej, ze szczególnym uwzględnieniem zróżnicowania przestrzeni europejskiej oraz procesów integracji europejskiej i uwarunkowań historycznych.

Slawomir Dorocki, PhD, Pedagogical University of Cracov, Institute of Geography, Department of Entrepreneurship and Spatial Management.

Sławomir Dorocki graduated from the Pedagogical University in Cracow with a MA degree in geography and a PhD in history (the Institute of European Studies of the Jagiellonian University). Adiunkt (assoc. professor) at the Pedagogical University of Cracow, the Institute of Geography. His research interests are tied with regional problems and processes of socio-economic regionalization, with particular emphasis on the diversity of Europe, processes of European integration and historical conditions.

Adres/Address: Uniwersytet Pedagogiczny im. Komisji Edukacji Narodowej w Krakowie Instytut Geografii

Zakład Przedsiębiorczości i Gospodarki Przestrzennej

ul. Podchorążych 2, 30-084 Kraków, Polska

e-mail: borowiec@up.krakow.pl

e-mail: sdorocki@up.krakow.pl 